\title{
price discrimination (empirical studies)
}

forthcoming in: The New Palgrave: a Dictionary in Economics, MacMillan

Price discrimination occurs when the prices of similar products sold by the same firm show variation that cannot be attributed to cost variation. Recent empirical work has identified the presence of both direct and indirect price discrimination, after cost-based explanations have been accounted for. Furthermore, there is increasing evidence on the sources of price discrimination. The extent of price discrimination has often been found to increase as competition intensifies, in contrast to conventional wisdom but consistent with new theoretical insights. Finally, various empirical studies have considered the effects of price discrimination on profits, consumer welfare and efficiency.

Price discrimination occurs when the prices of similar products sold by the same firm show variation that cannot be attributed to variation in marginal costs. Direct (or third-degree) price discrimination serves to exploit observed differences in consumer characteristics; indirect (or second-degree) price discrimination exploits unobservable consumer heterogeneity. While price discrimination has been studied extensively by economic theorists, and illustrated with numerous textbook examples (for example, Scherer and Ross, 1990), it has only recently become an area of rigorous empirical research. Empirical studies have focused on several questions: (a) the measurement or identification of price discrimination; $(b)$ the sources of price discrimination, notably the role of competition; and (c) the effects of price discrimination on profits, consumer welfare and efficiency.

\section{Measurement of price discrimination}

The identification of price discrimination can be introduced in a simple framework in which a firm sells two products. The price difference $\Delta p$ between the two products (assumed positive) can be decomposed in a cost difference $\Delta c$ and a margin difference $\Delta m$, so $\Delta p=\Delta c+\Delta m$. Price discrimination exists to the extent 
that the observed price difference $\Delta p$ is due to the margin difference $\Delta m$ rather than a possible cost difference $\Delta c$. (An alternative definition is based on percentage rather than absolute margin differences. To consider this, reinterpret the variables in logs. Clerides, 2004, compares the two approaches in empirical studies.) Identifying margin differences from cost differences is not an obvious task. Lott and Roberts (1991) provide plausible cost-based explanations for commonly viewed price discrimination cases. Several recent empirical studies have attempted to properly account for cost differences before drawing conclusions about the presence of price discrimination.

There have been two methodological approaches. The first approach uses direct cost information. Sometimes the cost difference can be derived from industry information about the production technology. An early example is Benston (1964), who finds that 76 per cent of the higher interest rates charged to small businesses can be attributed to additional costs. In contrast, Clerides (2002) attributes only five per cent of the average price difference between hardback and softback books to higher production costs. In other cases, the production technology is not known, but the cost difference $\Delta c$ is reasonably assumed to be zero or negative, so that the observed positive price difference $\Delta p$ provides a lower bound for the extent of price discrimination. Graddy (1995) finds that Asians pay seven per cent less at a fish market, while there are no reasons to believe that these customers have lower servicing costs. Degryse and Ongena (2005) find that bank customers pay lower interest rates as their distance from the bank increases, whereas costs, if anything, are expected to be increasing in distance. Shepard (1991) provides a neat variation on this theme. As in the above framework, she observes the price difference $\Delta p$ between a high-quality and a low-quality product sold by multi-product firms (full service and self-service at gas stations). In addition, she essentially also observes the analogue price difference $\Delta p^{S}$ for single-product firms (selling either full-service or selfservice). She defines the extent of price discrimination as the difference between the markup difference for multi-product firms $\Delta m$ and that of single-product firms $\Delta m^{S}$. Because her qualitative evidence indicates that the cost difference $\Delta c$ between the high-quality and low-quality product for multi-product firms is no larger than the corresponding cost difference $\Delta c^{S}$ for single-product firms, the difference between $\Delta p$ and $\Delta p^{S}$ provides a lower bound for the extent of price discrimination. She finds 
that the extent of price discrimination for full-service versus self-service gasoline amounts to at least nine cents a gallon.

The second approach to identifying price discrimination does not use cost information, but instead infers the price-cost margin difference $\Delta m$ from a model of pricing behaviour. This approach essentially replaces cost-side information by demand-side information. For example, Verboven (2002) finds evidence of indirect price discrimination between high-mileage and low-mileage drivers. He uses information on the relative popularity of high-quality and low-quality products (diesel and gasoline cars) and the distribution in consumers' willingness to pay for quality (mileage). He infers that 75-90 per cent of the price premium for the high-quality products can be attributed to a higher margin, a finding that is confirmed by direct cost information.

\section{Sources of price discrimination}

Several empirical studies have gone beyond the basic question of identifying price discrimination to uncover its sources, in particular the role of competition. Theoretical work has revealed that competition does not necessarily reduce the incentives to price discriminate. The extent of direct price discrimination depends on both the price elasticity of market demand and the cross-price elasticities with respect to competing products; it is therefore not necessarily smaller under competition. For example, Borenstein (1991) looks at price discrimination in the competitive retail gasoline market. Margins on unleaded gas were initially higher than margins on leaded gas. The decline in the number of competing stations offering leaded gas caused an increase in the margins on leaded gas relative to the margins on unleaded gas, hence a reduction in price discrimination. This illustrates that competition can be a source of price discrimination: stations take into account the buyers' possibilities to substitute to competing stations when setting their prices. Borenstein and Rose (1994) take up a similar question for the US airline industry. Since they observe more than two prices on a given airline/route, they use the Gini-coefficient as a summary measure of price dispersion (rather than the price difference $\Delta p$ for every product pair). They find that the expected price difference for two randomly selected passengers on a given airline/route is 36 per cent of the average ticket price. An increase in the number of competitors raises the extent of price dispersion by a large 
amount. Goldberg and Verboven (2001) measure margins based on the estimated own- and cross-price elasticities. They find that car manufacturers earn higher margins in their domestic markets than in their foreign markets, because markets are segmented according to country of origin and there is more competition in the foreign segments. Asplund, Eriksson and Strand (2002) find that newspaper subscriptions in Sweden are more often sold at (often introductory) discounts in duopoly regions than in monopoly regions. They interpret this as evidence of poaching, that is, discrimination to attract new customers from rival firms.

The existence of indirect price discrimination is not obvious under competition, as shown in theoretical work. Nevertheless, empirical work has documented that competition may strengthen indirect price discrimination. Verboven (1999) finds a significant percentage price premium for optional engine power in the more competitive car segments, and percentage discounts in the less competitive segments (the latter being consistent with a monopoly discrimination). Busse and Rysman (2005) compare the prices of large and small ads in Yellow Pages directories. Their identification strategy relies on the assumption that cost differences between the two types of ads do not depend on the degree of competition. As such, they do not measure the extent of price discrimination per se, but instead ask how it varies with competition. They find that competition raises the discounts to large buyers: adding one competitor lowers the price of small ads by only six per cent, whereas it lowers the price of large ads by 12 per cent.

\section{Economic effects of price discrimination}

Several empirical studies have also assessed the economic implications of price discrimination for profits, consumer welfare, tax revenues and economic efficiency. Leslie (2004) considers monopoly price discrimination. He finds that direct price discrimination for a Broadway theatre play, in the form of a currently observed 50 per cent discount at the discount booth known as the TKTS, raises profits five per cent above the profits under a uniform price strategy. However, he also finds that the current 50 per cent discount is too large to maximize profits, thereby generating too much substitution out of the full-price tickets. Lowering the discount to 30 per cent would raise profits seven per cent above the profits under a uniform price strategy. Leslie also estimates the aggregate consumer welfare effects from price discrimination, and finds them to be relatively small. 
Under competition, the effects of direct price discrimination on profits are ambiguous even if the discriminatory prices are chosen optimally. The possibility to discriminate may lead to a situation of all-out competition, in which all discriminatory prices are lower than the uniform prices, thereby reducing profits. This occurs when the weak (elastic) market of one firm is the strong (inelastic) market of the other firm. Nevo and Wolfram (2002) find suggestive evidence of all-out competition, documenting that price discrimination (in the form of coupons) may lower the prices of all products, and may hence lower profits. Besanko, Dubé and Gupta (2003) consider a situation of uniform pricing (for ketchup), and compute the new equilibrium under the assumption that firms would be able to discriminate between three (latent) customer segments. They find that all firms perceive the same customers as weak or strong. Price discrimination thus does not lead to all-out competition; quite the contrary, it increases profits. Brenkers and Verboven (2004) consider the reverse case in which car manufacturers currently discriminate between consumers from different countries, and would no longer be able to do this in the future (because of improved market integration). In their application, all-out competition appears more likely a priori, since domestic and foreign firms have the reverse strong and weak markets. Nevertheless, they find no evidence of all-out competition: an elimination of price discrimination would lower the prices of domestic firms, but raise the prices of foreign firms. Price discrimination correspondingly has relatively modest effects on industry profits and welfare (unless the high prices in the United Kingdom would be due to collusion).

The effects of indirect price discrimination under competition have also received attention recently. Miravete and Röller (2003) find that a single two-part tariff achieves 94 per cent of the potential profits and 63 per cent of potential welfare under a fully nonlinear tariff. McManus (2004) assesses the extent to which coffee shops distort their qualities (cup sizes) from the efficient levels, as a way to segment customers based on willingness to pay for quality. Consistent with economic theory, he finds that there are quality distortions, tending towards zero for the top qualities. Crawford and Shum (2006), using a somewhat different approach, also find evidence of quality degradation in the cable television industry. 
See also price discrimination (theory)

\section{Bibliography}

Asplund, M., Erikkson, R. and Strand, N. 2002. Price discrimination in oligopoly: evidence from Swedish newspapers. Discussion Paper No. 3269. London: CEPR.

Benston, G. 1964. Commercial bank price discrimination against small loans: an empirical study. Journal of Finance 19, 631-43.

Besanko, D., Dubé, J.-P. and Gupta, S. 2003. Competitive price discrimination strategies in a vertical channel using aggregate retail data. Management Science 49, 1121-38.

Borenstein, S. 1991. Selling costs and switching costs: explaining retail gasoline margins. RAND Journal of Economics 22, 354-69.

Borenstein, S. and Rose, N. 1994. Competition and price dispersion in the U.S. airline industry. Journal of Political Economy 102, 653-83.

Busse, M. and Rysman, M. 2005. Competition and price discrimination in Yellow Pages advertising. RAND Journal of Economics 36, 378-90.

Brenkers, R. and Verboven, F. 2006. Liberalizing a distribution system: the European car market. Journal of the European Economic Association 4(1), 216-251.

Clerides, S. 2002. Book value: intertemporal pricing and quality discrimination in the U.S. market for books. International Journal of Industrial Organization 20, $1358-408$.

Clerides, S. 2004. Price discrimination with differentiated products: definition and identification. Economic Inquiry 42, 402-12.

Crawford, G. and Shum, M. 2006. Monopoly quality degradation and regulation in cable television. Journal of Law and Economics (forthcoming).

Degryse, H. and Ongena, S. 2005. Distance, lending relationships and competition. Journal of Finance 60, 231-6.

Goldberg, P. and Verboven, F. 2001. The evolution of price dispersion in the European car market. Review of Economic Studies 68, 811-48.

Graddy, K. 1995. Testing for imperfect competition at the Fulton fish market. RAND Journal of Economics 26, 75-2.

Leslie, P. 2004. Price discrimination in Broadway theatre. RAND Journal of Economics 35, 520-41. 
Lott, J. and Roberts, R. 1991. A guide to the pitfalls of identifying price discrimination. Economic Inquiry 29, 14-23.

McManus, B. 2004. Nonlinear pricing in an oligopoly market: the case of specialty coffee. Mimeo. Olin School of Business, Washington University.

Miravete, E. and Röller, L. 2003. Competitive nonlinear pricing in duopoly equilibrium: the early U.S. cellular telephone industry. Discussion Paper No. 4069. London: CEPR.

Nevo, A. and Wolfram, C. 2002. Why do manufacturers issue coupons? An empirical analysis of breakfast cereals. RAND Journal of Economics 33, 319-39.

Scherer, F. and Ross, D. 1990. Industrial Market Structure and Economic Performance. Boston: Houghton Mifflin Company.

Shepard, A. 1991. Price discrimination and retail configuration. Journal of Political Economy 99, 30-53.

Verboven, F. 1999. Brand rivalry and market segmentation, with an application to the pricing of optional engine power on automobiles. Journal of Industrial Economics 47, 399-425.

Verboven, F. 2002. Quality-based price discrimination and tax incidence - the market for gasoline and diesel cars in Europe. RAND Journal of Economics 33, 27597. 